\title{
CODE-MIXING IN DIALOGUES AS SEEN IN ALICE COMIC BY ANGELLINA
}

\author{
Yashinta Farahsani ${ }^{1}$, Ika Puspita Rini ${ }^{2}$, Patria Handung Jaya ${ }^{3}$ \\ Department of Mechanical Engineering, Faculty of Engineering, Universitas Muhammadiyah \\ Yogyakarta, Yogyakarta, Indonesia ${ }^{1}$. Language Training Center, Universitas Muhammadiyah \\ Yogyakarta, Yogyakarta, Indonesia ${ }^{2,3}$ \\ yashinta_hime@yahoo.com ${ }^{1 *}$, azureforphieta@gmail.com ${ }^{2}$, patria.handung@gmail.com ${ }^{3}$
}

\begin{abstract}
Since English has become international language, Indonesian people prefer to mix their language using Indonesian and English rather than Indonesian and their mother tongue language. Indonesian comics are also showing this phenomenon. One of Indonesian comics which uses code-mixing in its dialogues is Alice by Angellina. Most of the dialogues in Alice use Indonesian-English code-mixing, besides the characters' names are also use Western names, instead of Indonesian names. The study focused on determining the types of code mixing: insertions, alternations, congruent lexicalizations (dialect) and the forms of words in the process of word-formation (such as noun, verb, adjective, phrase, and sentences). This study is a qualitative descriptive research. The research subject was taken from comic by Angellina entitled Alice (on Webtoons). The objects of the research were words, phrases, sentences and expressions which expressed in English. The tendency in using the code mixing is because some words have been used so often in the people's daily conversation in showing the emotions and sense.
\end{abstract}

Keywords: Alice; code-mixing; Indonesian comic; western phenomenon

\section{Introduction}

Language is sound symbol system that is used by members of a community to work together, interact, and identify themselves (Kridalaksana, 2009: 24). In addition, language is an important tool of communication among the members of a society. In the expression of culture, language is an essential aspect. It is the mean that conveys traditions and values related to group identity. During the processes of interpersonal communication, the problems of high importance are solved or discussed.Intercultural communication can be successful if the intercultural competences, which include the way people negotiate, meet, and greet, develop well. (Kolosova, 2011: 14 in Wulandari, 2016: 72).

Wardhaugh (2006: 1) states that society is any group of people who are drawn together for a certain purpose or purposes, while a language is what the members of a particular society speak. The study of language in relation to the society is called sociolinguistics. Sociolinguistics is a study which focuses on the relevance between language and society and it aims to find out how the society uses the language as a mean of communication as well as its structures. (Wardhaugh, 2006: 13).

The environment where people live can really influence the way they speak and the number of langauges they master. Nowadays, it is not a new thing that people become bilingual because they are able to speak more than one specific languages. Furthermore, they usually 
use it when they communicate with others. (Wulandari, 2016: 72). Kridalasana (2009: 36) defines that bilingual is when a person is able to speak using two languages, or when it is related to two language, such as people, society, transcription, dictionary, etc. In this modern era, more people are able to speak more than one languages, it can be two or more. They learn the languages in their environments, such as school, work place, society, etc. Therefore, the bilingual or multilingual phenomenon has been an ordinary thing in people's conversation, dialogues in movies, literatures, comics, etc.

Indonesian people is one of the examples in using bilingual language. They tend to use Indonesian and English at the same time. It is called code-mixing. Code-mixing is the change of one language to another within the same utterance or in the same oral/ written text (Yee Ho, 2007). Studies of code-mixing enhance our understanding of the nature, processes and constraints of language (Myers-Scotton, 1993a; Boeschoten, 1998; Azuma, 1998, Yee Ho, 2007), and of the relationship between language use and individual values, communicative strategies, language attitudes and functions within particular socio-cultural contexts. (Auer, 1998; Jacobson, 1998; Myers-Scotton, 1993b; Lüdi, 2003, Yee Ho, 2007). Code-mixing happens for several reasons, such as their background as like education, culture, social, economic, etcetera. In this case, education takes a big deal. The more the people are educated the more they use code-mixing. (Wulandari, 2016: 72).

In this research, it was discussed one comic taken from webtoon entitled Alice by Angellina. She is one of the authors who tends to use code-mixing in her works. She has written some comics which are published by webtoon, such as Alice, In a Dream, and iMarried. The last two comics are still on going until now, while Alice has already finished. The stories she makes are amazing and make the readers always curious about what will happen. She can make story plot interesting and unpredictable.

Alice is the first comic published in webtoon by Angellina on March 2016, and finished on April 2018. The story is about Alice, a girl who is from a rich family but gets violence from her father. She decides to move from her house and lives in a boarding house. There, she studies in an international school and meets many friends. The story goes until she finds her true love, Ben. However, the plot is not really interesting, but some dialogues in this comic can be analyze because of the author's tendency in using code-mixing in every comic she writes. Alice consists of 113 episodes and it was published once a week, every Thursday. The title of every episode is using English.

The language used is daily language. The characters even use the Indonesian slang language, so, it is easily understood by the readers. The dialogues in every panel were interesting made the readers felt entertained to read this comic. As an example of the dialogues that were spoken by the characters and used the code-mixing is a dialogue spoken by Sally to Sammy, "Aku ngerti kok kalo kamu belum move on sepenuhnya dari Alice." (Episode 75, panel 5). The sentence belongs to code-mixing because the speaker used one word or phrase of English into Indonesia language. The speakers master both languages so that they used it to 


\section{Available online di http://ejournal.undip.ac.id/index.php/humanika}

express their emotion, feeling or thought. It is found that there are variation forms and type code-mixing used.

Based on phenomenon above, the writer wants to investigate the style of code-mixing in Alice by Angellina. The study focused on determining the types of code-mixing and the forms of words in the process of word-formation. Muysken via Wibowo, Yuniasih, and Nelfianti (2017:17-18) stated that there are three main types of code-mixing processes in wordformation called insertion, alternation, and congruent lexicalization.

\section{Theoretical Framework}

\section{Code-Mixing}

As an international language, English is now used by many people all around the world. It is also supported by the existance of globalization and modernization. Not only as a whole unit, they sometimes mix English with their native language. This circumtances is known as code-mixing. According to Bokamba via Ayeomoni (2006: 91),

"code-mixing is the embeddin-g of various linguistic units such as affixes (bound morphemes), words (unbound morphemes), phrases and clauses from a cooperative activity where the participants, in order to infer what is intended, must reconcile what they hear with what they understand."

Furthermore, as Habib via Wibowo, Yuniasih, and Nelfianti (2017: 17), cited that codemixing emerge for several reasons such as expressing group identity, excluding other people when a comment is intended for only a limited audience, and because of real lexical need. It means that related to English, what has been stated by Bokamba and Habib means that sometimes, several words will be better described by using English. It also happens in comic "Alice" by Angelica. This comic character are teenagers and its target is also teenagers. In Indonesia, it is mostly teenagers who do a code-mixing of Indonesian and English. Besides, based on Kachru (1989), and Kamwangamalu (1989) via Ayeomoni (2006:91), code-mixing occurs due to modernization, westernization, efficiency, professionalism and social advancement.

\section{Type of Code-Mixing}

There are several theorists who mentioned types of code-mixing. However, the writers believe that the types of code-mixing according to Muysken via Wibowo, Yuniasih, and Nelfianti (2017:17-18) is more appropriate to be used as a mean of analyzing the data. Muysken divided it into three main types:

\section{Insertion (word phrase)}

In this type, the process of code-mixing is conceived as something borrowing. The speaker sometimes borrow either words or phrases. For example, besok malam mau dinner di mana? (Where will we have dinner tomorrow tonight?). The word "dinner" is taking the position of makan malam in Indonesian.

\section{Alternation}


Alternation type views the constraint on mixing the capability or equivalence of the language which is involved at the switch point. For example such English-Indonesian: "Gue mau ngesubmit makalh nih" (I am going to submit my paper). The prefix nge is involved to make it equivalence with Indonesian which means "doing the activity"

\section{Congruent lexicalization (dialect)}

It is a type of the situation where two languages share grammatical structures, which can be filled lexically with elements from either language. Similar grammatical structure here means the similarity of Subject and Verb position or the element in making a clause/sentence. For example, "Time management dia semester ini kacau banget". ("Her time management this semester is a mess")

\section{Research Method}

This study is a qualitative descriptive research. The research subject was taken from comic by Angelina entitled Alice (on Webtoons). The objects of the research were words, phrases, sentences and expressions which expressed in English. The technique of data collection was documentation method. Documentation method was used to find data about things that has been determined. By using this method, the writer could use free sentences.

First step of data collection technique was performing documentation technique to collect data from the comic entitled Alice by Angellina. The second step was data analysis. Since this research tried to find the types and forms of code-mixing, to analyze the data, this research used discourse analysis. The last step was identification and classification. During this step, the data were identified and classified based on their types and forms. The instruments used in this research were laptop and cell phone.

\section{Result and Duscussion Types of Code-Mixing}

Insertion (word phrase)

Approaching that depart from the notion of insertion new to constraint in term of the structural properties some base or matrix structures. Here the process of code-mixing is conceived as something borrowing. The insertion can be in the form of word or phrase. Indonesian has many borrowing words from English used by millennial generations for their communication, both in oral or written, for example: move on, stay, play boy, etc. Here are some examples in Alice dialogues which mention the insertion:

- Episode 1, Panel 31

The seller : Hahahha, ah si mas bisa aja. Kalo saya single mah, mau deh sama mas, cakep, lucu lagi. Ih, gemes deh. (Hahahha, oh please. If I'm single, I wanna be with you. You're handsome, and funny.)

Sammy : Bu, suaminya tuh bu. (Ms., your husband sees you.)

- Episode 2, Panel 1

Ben: Sudah sebulan lewat, Ben. Mau sampai kapan kamu pending kuliahnya? (It's been a month, Ben. Until when you are pending your study?)

- $\quad$ Episode 4, panel 24 
Alice: Ingat lah, kan Lala punya list cowok potensial. (Of course I remember. Lala has list of potential boys.)

Based on the examples above, the words single, pending, and list have been borrowed and become usual words to be used in oral language. In Indonesian, the word single has been borrowed and can be substituted with lajang in Indonesian. Nevertheless, most of Indonesian prefer to only change the spelling into singel and this word is really familiar among Indonesians. In the other hand, the words pending and list are actually can be subtituted with Indonesian words. Pending means menunda and list means daftar. When we these words are used in the sentences, it does not change the meaning, for example:

- Sudah sebulan lewat, Ben. Mau sampai kapan kamu pending kuliahnya? $\rightarrow$ Sudah sebulan lewat, Ben. Mau sampai kapan kamu tunda kuliahnya?

- $\quad$ Ingat lah, kan Lala punya list cowok potensial. $\rightarrow$ Ingat lah, kan Lala punya daftar cowok potensial.

With insertion, there is embedding. The English word is inserted into Indonesian structure. Insertion is a kind of spontaneous lexical borrwing, which is limited to one lexical unit.

\section{Alternation}

Approaches departing from alternation view the constraint on mixing in terms of capability or equivalence of the language involved at the switch point. Some English words has been used in Indonesian conversation, and added by suffix or infix. In some ways, it becomes Indonesian slang language, for example ngeprint, ngelist, di add, etc. Here are some examples in Alice dialogues which mention the alternation:

- $\quad$ Episode 4, Panel 69

Sammy : Boleh minta LINE ID? (May I get your LINE ID?)

Alice : Boleh. Buat grup aja ya. Nanti Lalanya di invite. (Sure. Let's make a group and Lala is invited.)

- Episode 20, panel 4-5

Ben : Ah! Make up artistnya, kamu dandan dulu ya. (Ah, the make up artist. Do make up first.)
Alice
: Okay. (Oke.)

- $\quad$ Episode 21, panel 73

Ben : Ngapain lu? (What are you doing?)

Sammy : Kartu breakfastnya buat dua orang. Buat gue aja besok biar ga mubazir. (The breakfast card is for two people. What about if this is for me tomorrow, so it is not wasteful.)

From the examples above, we can see that the English words are added by prefix (diinvite) and suffix (make up artist-nya and breakfast-nya). However, these words have been popular to use rather than using Indonesian. When people prefer to use make up artist rather than penata rias and breakfast rather than sarapan. In the case of alternation, there is a switch from one language to other, involving both grammar and lexicon. 


\section{Congruent lexicalization (dialect)}

- $\quad$ Episode 36

Ben : "Udah diurus semua. Aku keep it all private Marry, pake lawyer, soalnya harus urusan sama polisi juga. Kamu di mana?" (I have handled everything. I keep it all private, Marry. I have a lawyer because it involves police too. Where are you?")

"I keep it all private" clause replaced aku merahasiakan semuanya in Indonesian. Because the way in arranging the clause is similar in both languages, a congruent lexicalization occurs in this statement.

- $\quad$ Episode 15

Ben : " “..tapi perhatian kamu nggak ada artinya buatku. Stop wasting your time, Alice :" (...but, your sympathy is nothing for me. Stop wasting your time, Alice")

The phrase "Stop wasting your time, Alice" has the same grammatical structure in Indonesian- Berhentilah membuang waktumu, Alice. Hence, the lexicon can be directly replaced because not only does it have grammatical structure, but also its words structure is the same.

- Episode 33

Sam : "Thanks, udah bolehin make HP lu buat chat sama Alice." (Thanks for allowing me use your cell to chat with Alice)

Ben : "Sure..pake aja, anytime you miss her." (Sure. Just use it anytime you miss her")

Ben said "anytime you miss her" to replace kapanpun kamu kangen sama dia in Indonesian. A Congruent lexicalization happens here because the grammatical structure in both languages is similar.

The term congruent lexicalization refers to an utterance in which the two languages share a grammatical structure that can be filled lexically with elements from either language. The mixing between English and Indonesian interpreted as a combination of alternation and insertion.

\section{Forms of Code-Mixing}

\section{Words}

The code-mixing phenomena in oral and written language are usually in the form of words. In addition, the words are classified into word classes, such as noun, verb, and adjective.

- Noun

a. Episode 19, panel 29

Sammy : Iya, mau beli dessert ngga di sana? (Yes, would like to have dessert there?)

b. Episode 17, panel 20

Allen : Ngga bias, mesti 2 owner. (It can't be. It should be two owners.)

Ben : Jadi kafenya punya lu berdua? Nice. (So, the café is both of yours? Nice.)

c. Episode 19, panel 79 


\section{Available online di http://ejournal.undip.ac.id/index.php/humanika}

"Partner bisnis ayahku menikah, aku jadi bestmen." (My father's business partner is getting married, and I become the bestmen.)

- Verbs

a. Episode 17, panel 33

Sammy : Trus dapetnya yang kaya begitu? Bawel overload. Ato jadi orang yang gagal move on. (So, you guys got those kinds of girlfriends? Too captious. Or be a man who can't move on.)

b. Eposide 21, panel 63

Alice : Kamu kasihnya yang murah saja, nanti aku pakai. Aku tau ini mahal Ben, dan kamu bisa return ke tokonya. Kalo kasih ke aku percuma, aku ga pernah ke pesta, jangan buang-buang uang Ben.

(You just give me the cheap one, l'll wear it. I know it's expensive, Ben, and you can return it to the store. If you give it to me, it's useless. Don't waste your money.)

c. Episode 22, panel 60

Sammy : Nah kalo digabung gitu kan jadinya Alice love Sammy. (Then if it's combined, it turns into Alice loves Sammy.)

- Adjective

a. Episode 6, panel 44

"Ah, aku baper Sam." (I'm feeling you, Sam.")

"Itu udah punya cewek." (He has a girl.)

"Bohong." (You're lying.)

"Gabole gitu Sam, kamu juga imut kok." (Don't be like that, Sam. You're cute, too.)

"Sam cemburu ya? So sweet." (Sam is jealous. So sweet.)

b. Episode 8, panel 36

Sharon : Masaaa? Kenapa ga pacaran aja? Kalian cute banget berdua! liiih lucu!. (Oh really? Why are you not dating? You are both so cute! liih cute.)

c. Episode 8, panel 44

Sharon : Nanti, kalo udah agak lama, minta dibeliin ini ya! Nih liat, bagus kaaan? So pretty!! Ini belinya di Funk and Co, New Arrival, Pink Diamond. (Later, when it has been a while, you can ask to be bought this. See, it's beautiful. So Pretty!!. I bought it in Funk and Co, New Arrival, Pink Diamond.)

Phrase

- $\quad$ Episode 11

Ben : "Rapuh, sedih, butuh seseorang, trus ludateng. Jadian, happy ending." (Fragile, sad, need someone, and then you came. Dating, happy ending")

Sammy : "Tapi kenapa ngomingnya harus kasar? Nggak bias ngomongnya baik-baik?" (But why you should say it rudely? Can't you say it better?"

In the conversation between Ben and Sammy, Ben used "happy ending" phrase which replaced akhir yang bahagia in Indonesian. 
- $\quad$ Episode 17

Lala : "Jadi Sam sama Ben sebenernya naksir kamu. Terus mereka ga mau ama kamu karena mereka bro code gitu? Geer banget sih mau!!" (So, Sam and Ben have a crush on you but they don't want to be with you because they are friends? Like a bro code?

Alice's friend said "bro code" to replace aturan pertemanan or aturan persaudaraan in Indonesian. She preferred to use English because the situation is better to be described in English and the Indonesian version is rarely used.

- Episode 17

Allen : "Yah..gue ga tau deh dia lagi ada masalah apa, sampe nangis, ngomng ngga jelas. Abis itu nggak gue follow up lagi." ("Well, I don't know what's wrong with him. He cried and mumbling. After that, I didn't do any kinds of follow up action")

Menanyakan or mencari tahu lebih lanjut are phrases in Indonesian that was replaced by a simpler and shorter phrase "follow up" which makes it more efficient.

\section{Sentence}

- $\quad$ Episode 15

Ben : : “..tapi perhatian kamu ngga ada artinya buatku. Stop wasting your time,

Alice."(...but, your sympathy is nothing for me. Stop wasting your time, Alice")

In the conversation between Ben and Alice, Ben try to replace one phrase "Stop wasting your time, Alice" which means berhentilah membuang waktumu, Alice.

- $\quad$ Episode 8

Sharon : "Kurang ajar!! Aku pergi dulu! Mau gue samperin tokonya! Bye Alice! Bye ganteng! Mwackz." (How dare him! I'm going! I'll go to the store! Bye Alice! Bye handsome! Mwackz)

- $\quad$ Episode 17

"Yah well, happy birthday anyway. Nih hadiah ulang tahun. Makan, biar lu nggak stress." (Yah, well, happy birthday anyway. This is a birthday present. Eat this to release your stress.)

Code-mixing in the form of sentence have been used so often, especially for the English than has been use in daily conversation, such as thanks, bye, what's up, etc.

\section{Conclusion}

Indonesian people is one of the examples in using bilingual language. They tend to use both Indonesian and English at the same time. This situation is known as code-mixing. Code-mixing is the condition where someone changes one language to another within the same utterance or in the same oral/ written communication. Alice, a comic which is analyzed, indicates the existence of code-mixing because the speakers use words or phrases in both English and Indonesia language. The speakers use both languages to express their emotion, feeling or 
thought. It is found that there are variation forms and type code-mixing used. There are three types of code-mixing which is used to analyze the data: insertion, alternation, and congruent lexicalization (dialect). While the forms of code-mixing can be in the form of words, phrases, and sentences. For example:

1. word (...aku jadi bestmen...)

2. phrase (...Jadian, happy ending)

3. sentence (Stop wasting your time).

\section{References}

Angellina. 2016. Alice. March 2016 - April 2018. Webtoon Comics.

Ayeomoni. 2006. Code-Switching and Code-Mixing: Style of Language Use in Childhood in Yoruba Speech Community. Nigeria: Obafemi Awolowo University.

Kolosova, A. A. (2011). Intercultural competence or cultural intelligence, Bulgaria:

Info Invert.

Kridalaksana, Harimurti. 2009. Kamus Linguistik. Jakarta: PT. Gramedia Pustaka Utama

Lüdi, G. (2003) Code-Switching and Unbalanced Bilingualism. In Dewaele, J., Housen, A., and Li, W.(eds.) Bilingualism: Beyond Basic Principles, pp.174-188. Clevedon: Multilingual Matters

Myers-Scotton, C. (1993b) Social Motivations for Codeswitching. Oxford: Clarendon Press; New York: Oxford University Press.

Wardhaugh, R. (2006). An introduction to sociolinguistics (5th ed.). Australia: Blackwell.

Wibowo, Ary Iswanto, Indah Yuniasih, \& Fera Nelfianti. 2017. Analysis of Types Code Switching and Code Mixing by The Sixth President of Republic Indonesia's Speech at The National of Indpendence Day. PROGRESSIVE Vol. XII, No. 2 September 2017.

Wulandari, Santika. 2016. Indonesian-English Code Mixing in Raditya Dika's Manusia Setengah Salmon. Journal on English as a Foreign Language Vol. VI, No. 1 March 2016.

Yee Ho, Judy Woon. 2007. Code-Mixing: Linguistic Form and Socio-Cultural Meaning. The International Journal of Language Society and Culture. Issue 21 January 2007. 